\title{
KOMPOSISI GIZI DAN PATI TEPUNG BERAS RENDANG DARI BEBERAPA SENTRA PRODUKSI DI KOTA PAYAKUMBUH SUMATERA BARAT
}

\author{
Cesar Welya Refdi ${ }^{1}$ dan Prima Yaumil Fajri ${ }^{2}$ \\ ${ }^{1}$ Program Studi Teknologi Hasil Pertanian Fakultas Teknologi Pertanian Universitas Andalas \\ ${ }^{2}$ Program Studi Teknologi Hasil Pertanian Fakultas Teknologi Pertanian Universitas Jambi \\ Email: cesarwelya@gmail.com
}

\begin{abstract}
ABSTRAK
Penelitian ini bertujuan untuk mengetahui komposisi zat gizi dan pati Tepung Beras Rendang yang berasal dari beberapa sentra produksi di Kota Payakumbuh Sumatera Barat dan dibandingkan dengan Tepung Beras Ketan Putih (TBKP) sebagai bahan baku. Hal yang ingin diteliti adalah pengaruh perendangan tepung beras ketan terhadap komposisi gizi dan pati bahan. Komposisi gizi yang diamati adalah kadar air, kadar protein, kadar lemak, kadar abu, dan kadar karbohidrat, sedangkan komposisi pati yang diamati adalah kadar amilosa dan amilopektin bahan. Data yang diperoleh kemudian dianalisis secara statistik dengan Paired T-test (Uji T-berpasangan) menggunakan program SPSS 17. Berdasarkan hasil penelitian didapatkan bahwa proses perendangan TBKP memberikan pengaruh yang nyata $(\mathrm{P}<0,05)$ untuk menurunkan kadar air, kadar protein, kadar lemak dan secara nyata $(\mathrm{P}<0,05)$ meningkatkan kadar karbohidrat, kadar abu dan kadar amilosa.

Kata kunci-Tepung beras rendang, Nilai gizi, Pati, Perendangan
\end{abstract}

\section{PENDAHULUAN}

Pati serealia merupakan sumber utama karbohidrat, seperti beras, beras ketan hitam, beras ketan putih, gandum, barley dan lain-lain. Perbedaan sumber pati serealia menghasilkan sifat pati yang berbeda pula. Perbedaan sifat ini disebabkan oleh rasio amilosa-amilopektin. Beras putih yang biasa dikonsumsi masyarakat Indonesia adalah beras yang mengandung amilosa tinggi dibandingkan amilopektinnya, sehingga memberikan sifat pera dan kering. Salah satu serealia misalnya beras ketan putih. Beras ketan putih mengandung kadar amilopektin lebih banyak dibandingkan amilosanya (Belitz et al., 2008), sehingga memberikan sifat pulen yang khas ketan. Beras ketan ini banyak dimanfaatkan menjadi tepung ketan untuk diolah menjadi berbagai macam makanan.

Berbeda dengan pengolahan beras ketan putih pada umumnya, beras ketan putih di Sumatera Barat diolah secara tradisional menjadi "bareh randang" (beras rendang). Tepung beras rendang adalah tepung yang diperoleh dari hasil penggilingan beras ketan putih yang telah disangrai atau direndang di atas kuali hingga menguning tanpa tambahan bahan lain. Tepung inilah yang kemudian ditambahkan dengan gula kelapa dan dicetak menjadi makanan khas Sumatera Barat yang dikenal dengan "bareh randang" (beras rendang). Tepung beras rendang dan beras rendang banyak di produksi di Kota Payakumbuh, Sumatera Barat khususnya di daerah Napar, Kecamatan Payakumbuh Barat, Kota Payakumbuh.

Perendangan serealia juga banyak dilakukan di negara lain, seperti beras ketan hitam dan beras merah di Thailand, China, dan Srilanka (Sompong et al., 2011), beras cokelat di Thailand (Vittayaporn et al., 2010) dan Jepang. Perendangan beras di Thailand dan Korea (Lee, et al 2003), perendangan serealia di India dan perendangan gandum di Arab Saudi (Sandhu et al., 2015), perendangan gandum di China (Hu et al., 2011) dan perendangan barley di China (Omwamba et al., 2013) dan India (Baba et al., 2011 dan Mishra et al., 2014).

Perendangan berasal dari kata "rendang" yang berarti sebuah teknik memasak dengan panas yang berlangsung lama (Fajri et al., 2013). Rendang atau perendangan hampir sama dengan penyangraian. Menurut KBBI, penyangraian adalah proses pemasakan dengan memanfaatkan panas tanpa menggunakan minyak menggunakan kuali atau wajan. Metode pengolahan termal atau panas merupakan salah satu metode yang paling banyak dikembangkan. Pengolahan makanan ini dilakukan untuk meningkatkan cita rasa dan flavour makanan, mengurangi zat toksik dan upaya pengawetan makanan. Selama proses termal zat anti nutrisi berkurang atau hilang, selain itu juga dapat mengubah kandungan gizi dan sifat fungsional makanan (Arinola SO dan K Adesina, 2014). Oleh karena itu, 
tujuan dari penelitian ini adalah untuk mengetahui komposisi gizi dan pati tepung beras rendang dari beberapa sentra produksi di Kota Payakumbuh Sumatera Barat.

\section{METODOLOGI PENELITIAN}

\section{A. Bahan dan Alat}

Bahan yang digunakan dalam penelitian ini adalah tepung beras rendang yang diperoleh dari 3 (tiga) produsen beras rendang di Kota Payakumbuh, Sumatera Barat. Bahan-bahan kimia yang digunakan untuk analisis proksimat antara lain larutan aquades, Heksan, selenium mix, $\mathrm{H}_{2} \mathrm{SO}_{4}$ pekat, larutan $\mathrm{NaOH} 1 \mathrm{~N}$, larutan $\mathrm{H}_{3} \mathrm{BO}_{3}$, larutan $\mathrm{HCl}, \mathrm{Na}_{2} \mathrm{~S}_{2} \mathrm{O}_{3}, \mathrm{~K}_{2} \mathrm{SO}_{4} 10 \%$, metil merah $0,2 \%$ dalam alkohol, metil biru $0,2 \%$ dalam alkohol, $\mathrm{Na}_{2} \mathrm{CO}_{3}$ anhidrat, asam sitrat, $\mathrm{CuSO} 4.5 \mathrm{H}_{2} \mathrm{O}, \mathrm{KI} 20 \%$, etanol $95 \%$, Iodine. Peralatan untuk analisis kimia terdiri atas cawan porselin, cawan logam, oven, desikator, labu Kjeldahl, erlenmeyer, gelas ukur, kertas saring, Soxhlet, Spektrofotometer, kompor listrik, dan timbangan analitik.

\section{B. Prosedur Percobaan}

Penelitian tahap pertama yaitu melakukan survei lapangan ke tempat pengolahan tepung beras rendang di Kabupaten 50 Kota Sumatera Barat untuk mendapatkan informasi mengenai bahan baku dan pengambilan sampel. Sampel penelitian terdiri dari tepung beras ketan putih sebagai bahan baku pembuatan tepung beras rendang yang bersumber dari tempat yang sama (TBKP), kemudian tepung beras rendang diperoleh dari tiga tempat produksi beras rendang di Sentra Produksi Beras Rendang Kelurahan Napar yaitu Produsen Tepung Beras Rendang 1 (TBR1), Produsen Tepung Beras Rendang 2 (TBR2) dan Produsen Tepung Beras Rendang 3 (TBR3). Tahap kedua, kemudian dilakukan analisis kimia terhadap tepung beras ketan (TBKP) dan tepung beras rendang (TBR 1, TBR2, dan TBR 3) terdiri dari Analisis kadar air metode gravimetri (AOAC, 2005), Analisis kadar abu metode gravimetri (AOAC, 2005), Analisis kadar protein metode Mikro Kjedhal (AOAC, 2005), Analisis kadar lemak metode Soxhlet (AOAC, 2005) dan Kadar karbohidrat metode by different, Analisis kadar Pati (SNI 01-2892-1992), serta Kadar Amilosa (Apriyantono et al., 1998) dan Amilopektin.

\section{Analisis Data}

Penelitian ini menggunakan Paired T-test (Uji T-berpasangan) menggunakan program SPSS 17 dengan membandingkan tepung beras ketan putih dengan tepung beras rendang dari tiga tempat produksi pengolahan.

\section{HASIL DAN PEMBAHASAN}

Berdasarkan hasil analisis proksimat yang dilakukan untuk mengetahui komposisi gizi dari Tepung Beras Ketan Putih (TBKP) dan Tepung Beras Rendang (TBR) diperoleh hasil yang ditunjukkan pada Tabel 1.

Tabel 1. Komposisi Gizi Tepung Beras Ketan Putih (TBKP) dan Tepung Beras Rendang (TBR)

\begin{tabular}{lccccc}
\hline \multirow{2}{*}{ Sampel } & \multicolumn{5}{c}{ Kadar $(\%)$} \\
\cline { 2 - 6 } & Air & Protein & Lemak & Abu & Karbohidrat \\
\hline TBKP & $11,09 \pm 0,10$ & $15,49 \pm 0.33$ & $1,18 \pm 0,01$ & $0,36 \pm 0.02$ & $71,88 \pm 0,27$ \\
TBR 1 & $8,58 \pm 0,30^{*}$ & $15,33 \pm 0.44$ & $0,88 \pm 0,03^{*}$ & $0,43 \pm 0.02^{*}$ & $74,78 \pm 0,13^{*}$ \\
TBR 2 & $16,96 \pm 0,71^{*}$ & $12,91 \pm 0,63^{*}$ & $1,10 \pm 0,07$ & $0,68 \pm 0,06^{*}$ & $68,35 \pm 1,17^{*}$ \\
TBR 3 & $11,04 \pm 0,22$ & $12,19 \pm 0,85^{*}$ & $0,76 \pm 0,05^{*}$ & $0,41 \pm 0,02^{*}$ & $75,6 \pm 1,08^{*}$
\end{tabular}

Keterangan: superskrip dengan simbol (*) pada kolom yang sama menunjukkan beda nyata $(\mathrm{P}<0,05)$ terhadap TBKP 


\section{A. Kadar Air}

Hasil analisis kadar air menunjukkan bahwa kadar air TBKP merupakan yang tertinggi dan TBR 1 mempunyai kadar air yang terendah. Berdasarkan Paired T-test (uji T-berpasangan) menunjukkan bahwa kadar air TBR 1 berbeda nyata dengan kadar air TBKP $(\mathrm{P}<0.05) . \quad$ TBR 1 memiliki kadar air sangat nyata lebih rendah dibandingkan dengan TBKP. Hal ini menunjukkan adanya penurunan kadar air akibat proses perendangan. Ini sejalan dengan hasil penelitian yang telah dilakukan oleh Ravi et al., (2015) yang menyatakan bahwa perendangan pada tepung akan mengakibatkan terjadinya penguapan air bahan dan menurunkan kadar air akhir tepung setelah perendangan.

TBR 3 tidak menunjukkan adanya perbedaan yang nyata dengan TBKP. Hal ini diduga disebabkan oleh suhu perendangan tidak cukup tinggi untuk menurunkan kadar air TBR 3. Sedangkan TBR 2 memperlihatkan adanya peningkatan kadar air yang nyata dibandingan dengan TBKP, ini kemungkinan disebabkan setelah proses perendangan dilakukan TBR 3 langsung dikemas kedap udara sehingga uap air yang dihasilkan kembali terserap oleh bahan dan dapat meningkatkan kadar airnya.

\section{B. Kadar Protein}

Berdasarkan Paired T-test (Uji T-berpasangan) memperlihatkan bahwa terjadi penurunan yang nyata $(\mathrm{P}<0,05)$ pada kadar protein TBR 2 dan TBR 3 dibandingkan dengan kadar protein TBKP. Sedangkan pada TBR 1 kadar proteinnya tidak berbeda nyata $(\mathrm{P}<0,05)$ dengan kadar protein TBKP.

Terjadinya penurunan kadar protein pada TBR 2 dan TBR 3 diduga disebabkan oleh proses perendangan yang dilakukan oleh produsen beras rendang tersebut menggunakan suhu yang cukup tinggi dan berlangsung cukup lama sehingga mengakibatkan terjadinya denaturasi protein. Denaturasi protein merupakan kerusakan struktur protein bahan, salah satu penyebabnya adalah penggunaan panas yang cukup tinggi dan dalam waktu yang lama. Proses denaturasi protein oleh panas disebabkan rusaknya ikatan hidrogen dan interaksi hidrofobik nonpolar protein (Asrullah et al., 2012). Hal ini akan berdampak pada penurunan kadar protein bahan.

Namun, kadar protein TBR 1 tidak berbeda nyata dengan kadar protein TBKP, hal ini diduga karena suhu perendangan tidak cukup tinggi dan berlangsung singkat sehingga tidak mengakibatkan terjadinya denaturasi protein pada bahan. Hasil ini sejalan dengan hasil penelitian yang telah dilakukan oleh Sulthoniyah et al., (2013) yang mengemukakan bahwa panas yang tinggi dapat menurunkan kadar protein bahan.

\section{Kadar lemak}

Berdasarkan Paired T-test (Uji T-berpasangan) yang telah dilakukan menunjukkan bahwa terjadi penurunan kadar lemak yang nyata $(\mathrm{P}<0,05)$ antara TBR 1 dan TBR 3 dengan TBKP. Hal ini dapat terjadi karena proses perendangan mengakibatkan lemak mengalami kerusakan dan mengakibatkan penurunan kadar lemak bahan. Sifat lemak yang tidak tahan terhadap panas, selama proses perendangan mengakibatkan lemak mencair bahkan menguap (volatile) menjadi komponen lain seperti flavor. Sesuai dengan pernyataan Sundari et al., (2015) bahwa tingkat kerusakan lemak sangat bervariasi tergantung pada suhu yang digunakan dan lamanya proses pengolahan. Makin tinggi suhu yang digunakan maka semakin intens kerusakan lemak yang terjadi. Hal ini sesuai dengan penelitian Llyold et al., (2000), yang menunjukkan bahwa beberapa proses pengolahan dengan suhu tinggi $(\geq 100$ ${ }^{\circ} \mathrm{C}$ ) dapat menurunkan kadar lemak beras pecah kulit akibat berkurangnya komponen lemak yang sensitif terhadap panas seperti orizanol, tokotrienol dan tokoferol. Sedangkan kadar lemak TBR 2 tidak berbeda nyata dengan TBKP $(\mathrm{P}>0,05)$. Hal ini dapat terjadi diduga karena suhu dan waktu perendangan tidak cukup untuk menguapkan lemak yang ada di dalam TBR 2, sehingga kadar lemaknya tidak berkurang.

\section{Kadar abu}

Berdasarkan hasil analisis kadar abu yang diuji dengan Paired T-test (Uji T-berpasangan), menunjukkan kadar abu meningkat secara nyata $(\mathrm{P}<0,05)$ antara TBR 1 , TBR 2 dan TBR 3 terhadap TBKP. Hal ini menunjukkan bahwa proses perendangan mengakibatkan peningkatan kadar abu. Hal ini diduga terjadi akibat interaksi peralatan logam yang digunakan selama proses perendangan. Ini sejalan 
dengan pernyataan Faria et al., (2012) yang menyatakan bahwa kemungkinan interaksi antara peralatan pengolahan dengan bahan tidak bisa diabaikan.

\section{E. Kadar Karbohidrat}

Kadar karbohidrat dalam penelitian ini diperoleh dengan metode by difference. Berdasarkan hasil perhitungan karbohidrat diperoleh kadar karbohidrat TBKP 71,88 $\pm 0,27 \%$, TBR1 74,78 $\pm 0,13$, TBR2 68,35 $\pm 1,17 \%$, TBR3 75,6 $\pm 1,08 \%$. Berdasarkan dengan Paired T-test (Uji T-berpasangan), jika dibandingkan antara kadar karbohidrat TBKP dengan TBR1, TBR2 dan TBR3 maka diperoleh perbedaan secara nyata $(\mathrm{P}<0,05)$. Peningkatan terjadi pada TBR1 dan TBR3, sedangkan kadar karbohidrat TBR2 mengalami penurunan akibat perendangan. Hal ini dipengaruhi juga oleh kandungan gizi lain yang mengalami peningkatan dan penurunan.

\section{F. Komposisi Pati}

Hasil analisis komposisi pati yang dilakukan pada Tepung Beras Ketan Putih (TBKP) dan Tepung Beras Rendang (TBR 1, TBR 2 dan TBR 3) ditunjukkan pada Tabel 2.

Tabel 2. Komposisi Pati

\begin{tabular}{lccc}
\hline \multirow{2}{*}{ Sampel } & \multicolumn{3}{c}{ Kadar (\%) } \\
\cline { 2 - 4 } & Pati & Amilosa & Amilopektin \\
\hline TBKP & $71.36 \pm 0.11$ & $5.33 \pm 0.44$ & $66.03 \pm 0.49$ \\
TBR 1 & $71.80 \pm 0.48$ & $7.13 \pm 0.68^{*}$ & $64.68 \pm 0.35$ \\
TBR 2 & $66.34 \pm 5.45$ & $13.26 \pm 1.03^{*}$ & $53.07 \pm 4.46^{*}$ \\
TBR 3 & $71.21 \pm 4.53$ & $7.59 \pm 0.51^{*}$ & $63.62 \pm 4.97$ \\
\hline
\end{tabular}

Keterangan: superskrip dengan simbol (*) pada kolom yang sama menunjukkan beda nyata $(\mathrm{P}<0,05)$ terhadap TBKP

Perbandingan kadar amilosa dan amilopektin suatu bahan sumber karbohidrat menunjukkan sifat fisikokimia dari bahan tersebut. Berdasarkan data yang diperoleh terlihat bahwa TBKP yang diolah dengan perendangan (TBR 1, TBR 2 dan TBR 3) mengakibatkan meningkatnya kadar amilosa secara nyata $(\mathrm{P}<0,05)$ dan menurunkan kadar amilopektin. Hal ini sesuai dengan hasil penelitian Mahadevamma et al., (2003) yang menunjukkan terjadinya degradasi molekul amilopektin menjadi molekul amilosa rantai pendek akibat pemanasan. Selain itu, Faridah et al., (2010), akibat perlakuan pemanasan-pendinginan menunjukkan kadar fraksi amilopektin pati garut menurun dan fraksi amilosa mengalami peningkatan.

\section{KESIMPULAN}

Berdasarkan hasil penelitian yang telah dilakukan dapat disimpulkan bahwa perendangan yang dilakukan terhadap tepung beras ketan putih di beberapa sentra produksi tepung beras rendang di Kota Payakumbuh memberikan pengaruh terhadap perubahan komposisi gizi dan pati bahan.

\section{DAFTAR PUSTAKA}

AOAC. 2005. Offical Methods of Analysis. 16th ed. AOAC Int., Washington D. C.

Arinola SO dan K Adesina. 2014. Effect of Thermal Processing on the Nutritional, Antinutritional, and Antioxidant Properties of Tetracarpidium conophorum (African Walnut). Journal of Food Processing. http://dx.doi.org/10.1155/2014/418380

Asrullah Muhammad, Ayu Mardiyanti Mathar, Citrakesumasari, Nurhaedar Jafar, St Fatimah. 2012. Denaturasi dan Daya Cerna Protein PADA Proses Pengolahan Lawa Bale (Makanan Tradisional Sulawesi Selatan). Media Gizi Masyarakat Indonesia. 1 (2): 84-90. 
Baba WN, I Rashid, A Shah, M Ahmad, A Gani, FA Masoodi, IA Wani, SM Wani. 2016. Effect of Microwave Roasting on Antioxidant and Anticancerous Activity of Barley Flour. Journal of the Saudi Society of Agricultural Sciences. 12-19. http://dx.doi.org/10.1016/j.jssas.2014.06.003

Belitz H D, Grosth, W \& Schieberle, P. 2008. Food Chemistry. 4th ed. Springer Verlag. Berlin.

Fajri Prima Yaumil, Made Astawan, Tutik Wresdiyati. 2013. Evaluasi Nilai Gizi Protein Rendang dan Kalio Khas Sumatera Barat. Jurnal Penelitian Gizi dan Makanan. 36(2): 113-120.

Faria Simone Aparecida dos Santos Conceicao, Bassinello PZ, Penteado Marilene de Vuono CP. 2012. Nutritional Composition of Rice Bran Submitted to Different Stabilization Procedures. Brazilian Journal of Pharmaceutical Science. 48 (4): 651-657.

Faridah DN, Dedi F, Nuri A, Titi CS. 2010. Perubahan Struktur Pati Garut (Maranta arundinaceae) sebagai akibat Modifikasi Hidrolisis Asam, Pemotongan Titik Percabangan dan Siklus Pemanasan-Pendinginan. Jurnal Teknologi dan Industri Pangan. 21 (2) : 135-142.

Hu X, J Yan, X Xing. 2011. The Effects of Steaming And Roasting Treatments on Lipase Activity and Nutritional Components of "Oat Rice" (Or) : The Peeled Naked Oat (Avena Nuda) Kernels. Agricultural science. 2(2) : 56-60.

Lee, GC, SJ Kim, BK Koh. 2003.Effect of Roasting Condition on the Physicochemical Properties of Rice Flour and the Quality Characteristics of Tarakjuk. Korean J Food Sci Technol. 35 (5): 905-913.

Lloyd BJ, Siebenmorgen TJ, Beers KW. 2000. Effects of Commercial Processing on Antioxidant in Rice Bran. Cereal chem. 77 (5) : 551-555.

Mahadevamma MS, Harish KVP, Tarathanan RN. 2003. Resistent Starch Derived Processed Legumes: Purification and Structural Characterization. Journal of Carbohydrate Polymers. 54: 215-219.

Mishra V, N Yadav, V Puranik. 2014. Effect of Procesing Methods on The Nutraceutical and Antioxidant Properties of Red Rice (Oryza Nivara). International Journal of Food and Nutritional Sciences. 3: 98-103.

Omwamba M, Feng Li, Gujiu San, Qiuhui. 2013. Antioxidant Effect of Roasted Barley (Hordeum vulgare L.) Grain Extract towards Oxidative Stress in Vitro and in Vivo. Food Nutrition Sciences. 4: 139-146.

Ravi U, Lakshmi Menon, Maria Hepzibah A, Shivangi Saha. 2015. Flour Pretreatment on The Quality Characteristics and Oil Absorption of Traditional South Indian Festive Snack. Indian Journal of Traditional Knowledge. 1 (1): 139-143.

Sandhu KS, P Godara, M Kaur, S Punia. 2015. Journal of the Saudi Society of Agricultural Sciences. http://dx.doi.org/10.1016/j.jssas.2015.06.004

Sompong R, S Siebenhandl-Ehn, G. Linsberger-Martin, E Berghofer. 2011. Physicochemical and Antioxidative Properties of Red and Black Rice Varieties from Thailand, China and Sri Lanka. Food Chemistry.124: 132-140.

Sulthoniyah STM, Titik Dwi Sulistiyati, Eddy Suprayitno. 2012. Pengaruh Suhu Pengukusan Terhadap Kandungan Gizi dan Organoleptik Abon Ikan Gabus (Ophiocephalus striatus). 1 (1): 33-45.

Sundari Dian, Almasyhuri, Astuti Lamid. 2015. Pengaruh Proses Pemasakan Terhadap Komposisi Zat Gizi Bahan Pangan Sumber Protein. Media Litbangkes. 25 (4): 235-242.

Vittayaporn V, P Chompreeda, V Haruthaithanasan, H Rimkeeree. 2010. Preference Mapping of Thai Consumers for Commercial Green Tea with Roasted Brown Rice. Kasetsart J (Nat. Sci.). 44: 652-633 